Удк 502.172(477.72)

DOI https://doi.org/10.32851/2708-0366/2020.4.18

Присяжнюк П.В.

аспірант,

Херсонський державний аграрно-економічний університет

ORCID: https://orcid.org/0000-0001-8009-6185

Prisyajnyuk Peter

Kherson State Agrarian and Economic University

\title{
РОЗШИРЕННЯ ПРИРОДНО-ЗАПОВІДНОГО ФОНДУ ХЕРСОНЩИНИ: ПРОБЛЕМИ ТА ПЕРСПЕКТИВИ
}

\section{EXPANSION OF KERSON REGION NATURE RESERVE FUND: PROBLEMS AND PROSPECTS}

\begin{abstract}
Розширення переліку об'єктів природно-заповідного фонду (далі - ПЗФ) Херсонської області та збереження наявних заповідних територій мають позитивний ефект щзодо розвитку рекреаційної, оздоровчої, туристичної діяльності. У статті досліджено основну нормативно-правову базу, щчо регулює всі етапи формування ПЗФ краӥни й регіону. Проаналізовано стан заповідання та переведення об 'єктів Херсонщини до ПЗФ. Наведено кількісний склад об'єктів Херсонщини по районах, які входять до перспективного плану заповідання найближчим часом. Перелік об' 'ктів під заповідання, щзо знаходяться в регіоні, є широким, а також є ті об'єкти, які вже перебувають на межі винимення, тому слід вжити низку заходів, які сформують належні умови для збереження первозданності місцеевої флори та фауни. У зв'язку з цим визначено групи основних факторів, які стримують реалізацію иього прочесу для того, щзоби сформувати низку стратегічних і тактичних завдань щуодо мінімізації їх впливу.
\end{abstract}

Ключові слова: заповідання, природно-заповідний фонд, перспективний план, регіональний розвиток, розвиток територій.

Расширение перечня объектов природно-заповедного фонда (далее - ПЗФ) Херсонской области и сохранение существующих заповедных территорий имеют положительньй эффект касательно развития рекреационной, оздоровительной, туристической деятельности. В статье исследована основная нормативно-правовая база, регулирующая все этапы формирования ПЗФ страны и региона. Проанализировано состояние завещзания $и$ перевода объектов Херсонской области в ПЗФ. Приведен количественный состав объектов Херсонской области по районам, которые входят в перспективный план заповедания в ближайшее время. Перечень объектов под заповедание, находящихся в регионе, является широким, а также есть те объекты, которые уже находятся на грани уничтожения, поэтому следует принять ряд мер, которые сформируют необходимые условия для сохранения первозданности местной флоры и фауныл. В связи с этим определены группь основных факторов, сдерживающих реализачию этого прочесса для того, чтобь сформировать ряд стратегических и тактических заданий по минимизации их воздействия.

Ключевые слова: заповедание, природно-заповедный фонд, перспективный план, региональное развитие, развитие территорий.

The territory of Kherson region is located in favorable natural and geographical conditions, has a strong natural resource potential and a rich nature reserve fund, which is an important basis of life and needs to expand. Preservation of wildlife is a priority for human development, because our own existence depends on maintaining life on Earth. This is extremely relevant for regions that have been greatly altered by human activities. If you look at the map of anthropogenic transformation in the Ecological Atlas of Ukraine, it is noticeable that Kherson region is the most synanthropized among all regions in our country. Steppe landscapes were particularly affected, mainly due to plowing. That is why in conditions of very strong anthropogenic pressure the importance of nature reserves increases. The formation of a network of nature reserves is an important measure of strategic planning for the development of the country and should be 
consistent with the needs of economic and social development of the country. Expansion of the list of objects of the nature reserve fund (further PZF) of the Kherson area and preservation of the existing reserved territories has positive effect in the direction of development of recreational, improving, tourist activity. The article examines the main legal framework governing all stages of the formation of the NPF of the country and the region. The state of bequest and transfer of objects of Kherson region to PZF is analyzed. The quantitative composition of the objects of Kherson region by districts, which are included in the perspective plan for wills in the near future, is given. In total, in the Kherson region it is proposed to create 125 new objects of nature reserve fund, including 3 regional landscape parks, 71 reserves and 51 natural monuments. The list of objects under the will located in the region is wide and there are those objects that are already on the verge of extinction, so a number of measures should be taken that will create appropriate conditions to preserve the originality of the local flora and fauna. Therefore, groups of the main factors that hinder the implementation of this process in order to form a number of strategic and tactical tasks to minimize their impact have been identified.

Key words: wills, nature reserve fund, perspective plan, regional development, development of territories.

Постановка проблеми. Нині на державному рівні згідно з вимогами Стратегії регіонального розвитку, що затверджена Постановою Кабінету Міністрів України від 6 серпня 2014 р. № 385, на території України з 2014 р. до 2017 р. мали б уже бути створені об’єкти природно-заповідного фонду з площею 6733000 га, а у 2021 р. - 9095000 га. Частка заповідних територій має становити на 1 січня 2017 р. 11\%, а на початок січня 2021 р. 15\% від площі держави; частка заповідання природоохоронних об’єктів від наявних для Херсонської області у 2013 р. була визначена на рівні 7,9\% (224 800 га), у 2017 р. 13,1\% (372 800 га), а до 2021 р. цей показник має становити 17,9\% (509 500 га). Фактичний стан віднесення об'єктів до природно-заповідного фонду на Херсонщині не відповідає перспективним планам у цьому напрямі та навіть не наближається сьогодні до показника 2017 р. [4]. У сучасних реаліях цей процес унеможливлюється через низку чинників, які стримують процеси розширення природно-заповідного фонду регіону, тому перед науковцями, вченими, держаними службовцями та тими, хто безпосередньо зацікавлений у збереженні первозданної краси унікальної флори й фауни Херсонщини, постає завдання визначитися 3 основними чинниками та окреслити механізми щодо унеможливлення їх суттєвих проявів на шляху до створення ефективної екомережі регіону. Формування мережі природно-заповідного фонду відповідно до Стратегії регіонального розвитку є важливим фактором на шляху планування розвитку території регіонів, що має бути взаємоузгоджене з потребами економічного та соціального розвитку держави й приведе до створення ефективної, дієвої системи щодо заповідання територій як для конкретно взятого регіону, так і для всієї країни.

Аналіз останніх досліджень і публікацій. Вивченням питань щодо формування переліку перспективних об'єктів для заповідання в Херсонській області та визначенням чинників, що стримують цей процес, займаються досить тривалий час такі вітчизняні вчені, як М.Ф. Бойко, В.В. Дармостук, М.Я. Захарова, В.М. Клименко, Д.С. Мальчикова, I.І. Мойсієнко, І.О. Пилипенко, А.А. Пономарьова, О.Є. Ходосовцев [3; 4]. Ними на сьогодні виділено 125 нових, перспективних об'єктів природно-заповідного фонду, серед яких 3 регіональні ландшафтні парки, 71 заказник та 51 пам'ятка природи, які потребують заповідання задля збереження первозданної краси унікальної флори й фауни Херсонської області. Водночас науковцями наведено перелік чинників, які вже не один рік перешкоджають процесу переведення цих об'єктів до природно-заповідного фонду. Наявні фактори потребують подальшого вивчення та опрацювання задля пошуку дієвих механізмів, які б запобігали їх негативним проявам.

Формулювання цілей статті. Метою статті $\epsilon$ аналіз стану розширення природно-заповідного фонду Херсонщини та визначення групи основних факторів, які стримують реалізацію цього процесу. 
Виклад основного матеріалу. Збереження природних особливостей та їх примноження сьогодні є одним із суттєвих пріоритетів у регіональному розвитку. Це створює додаткові передумови для економічного, екологічного, соціокультурного розвитку регіону та активізації в Херсонській області таких напрямів туризму, як культурно-пізнавальний, екскурсійний, рекреаційний, екологічний, зелений, а це приводить до отримання регіоном від цього додаткових фінансових коштів, які, зокрема, будуть спрямовані на охорону та збереження об'єктів природно-заповідного фонду (далі - ПЗФ).

Створення та розширення ПЗФ регіону розпочинаються перш за все з наявності заповідних об'єктів, площ залишків природних ділянок та вжиття заходів з активізації роботи над амбіційними проєктами, що підлягають заповіданню. Всі ці процеси регулюються низкою законодавчих актів, в межах яких відбувається переведення територій до категорії об’єктів, які мають особливу природоохоронну, наукову, естетичну та рекреаційну цінність.

До основної нормативно-правової бази, що регулює всі етапи формування ПЗФ країни й регіону, належить низка правових актів, перелік яких представлений у табл. 1.

Таблиця 1

Перелік основних нормоутворюючих актів, що регулюють процеси створення ПЗФ в Україні

\begin{tabular}{|c|c|c|}
\hline № & $\begin{array}{c}\text { Основні нормативно-правові } \\
\text { документи }\end{array}$ & $\begin{array}{c}\text { Ключові положення, які регулюються } \\
\text { нормативно-правовим актом }\end{array}$ \\
\hline 1. & $\begin{array}{l}\text { Закон України «Про природ- } \\
\text { но-заповідний фонд України» від } \\
16 \text { червня } 1992 \text { р. № 2456-XII }\end{array}$ & $\begin{array}{l}\text { Визначає правові основи організації, охорони, ефек- } \\
\text { тивного використання природно-заповідного фонду } \\
\text { України, відтворення його природних комплексів та } \\
\text { об'єктів. }\end{array}$ \\
\hline 2. & $\begin{array}{l}\text { Указ Президента «Про Цілі ста- } \\
\text { лого розвитку України на період } \\
\text { до } 2030 \text { року» № } 722 / 2019\end{array}$ & $\begin{array}{l}\text { Визначено створення нових територій природно-за- } \\
\text { повідного фонду, передбачено потроєння площі за- } \\
\text { повідних територій до } 2030 \text { р. }\end{array}$ \\
\hline 3. & $\begin{array}{l}\text { Постанова Кабінету Міністрів } \\
\text { України «Про затвердження дер- } \\
\text { жавної стратегії регіонального } \\
\text { розвитку на період до } 2020 \text { року» } \\
\text { від } 6 \text { серпня } 2014 \text { р. № } 385\end{array}$ & $\begin{array}{l}\text { Передбачає раціональне використання рекреаційних } \\
\text { ресурсів територій та об'єктів природно-заповідно- } \\
\text { го фонду для формування економічного середовища } \\
\text { та розвитку сфери зайнятості населення в регіонах. } \\
\text { Підвищує рівень обізнаності населення щодо цін- } \\
\text { ностей територій та об'єктів природно-заповідного } \\
\text { фонду й залучення населення до управління ними. }\end{array}$ \\
\hline 4. & $\begin{array}{l}\text { Розпорядження Кабінету Міні- } \\
\text { стрів України «Про схвалення кон- } \\
\text { цепції Загальнодержавної прог- } \\
\text { рами збереження біорізноманіття } \\
\text { на } 2005-2025 \text { роки» від } 22 \text { верес- } \\
\text { ня } 2004 \text { р. № 675-р }\end{array}$ & $\begin{array}{l}\text { Окреслено основні пріоритети державної політики у } \\
\text { сфері природокористування, екологічної безпеки та } \\
\text { охорони довкілля, що є невід’ємною умовою поліп- } \\
\text { шення стану довкілля та екологічно збалансованого } \\
\text { соціально-економічного розвитку. }\end{array}$ \\
\hline
\end{tabular}

Джерело: сформовано на основі [4; 7]

Проаналізований перелік нормативних актів формує правову базу, яка регулює основні процеси щодо захисту флори та фауни в середовищі їх існування, збереження біологічного різноманіття та сталого використання й відтворення ПЗФ. У наведених законодавчих документах прописані «правила гри» щодо ведення діяльності у сфері охорони біологічного та ландшафтного різноманіття, що забезпечує збереження його первозданного виду та спонукає до переводу об'єктів під заповідання та розширення ПЗФ. Однак, незважаючи на це, у країні та регіонах створення нових територій ПЗФ 
через заповідання територій не має тих темпів, які встановлені цими нормативно-правовими актами, а все це відбувається через наявність факторів, які гальмують та унеможливлюють ці процеси.

Аналізуючи стан заповідання та переведення об’єктів Херсонщини до природно заповідного фонду, бачимо, що сьогодні ситуація така: регіон налічує у своєму складі 82 об’єкти (загальною площею 370 836,7 га), з яких 16 об'єктів загальнодержавного значення і 66 об'єктів місцевого значення. Показник заповідності області за період незалежності країни зріс із 6,4\% (182 907 га) у 1991 р. до 10,9\% (182 907 га) у 2019 р. Водночас, враховуючи законодавчо-правові акти та перспективні плани щодо цього, бачимо, що регіон відстає від запланованих показників, адже у 2017 р. показник заповідання мав бути 13,1\%, а він порівняно з 2019 р. нижче на 2,1 в. п. і навряд чи у 2021 р. дійде до запланованих 17,9\%. Повільний стан заповідання зумовлений також тим, що серед наявних площ, які віднесені до природно-заповідного фонду, близько 120000 га (майже 4\%) становлять акваторії морів, лиманів, заток, тому площа заповідних територій області вкрай недостатня [3].

Водночас регіон має достатню кількість територій, які з огляду на свою природну, історичну, культурну цінність мають бути переведені до ПЗФ загальнодержавного чи місцевого значення. Сьогодні вченими сформовано перспективний план заповідання території Херсонщини, на рис. 1 відображено кількісний склад об'єктів відповідно до новоутворених територіальних одиниць регіону, які в майбутньому мають поповнити наявний перелік об’єктів, що увійдуть до ПЗФ області.

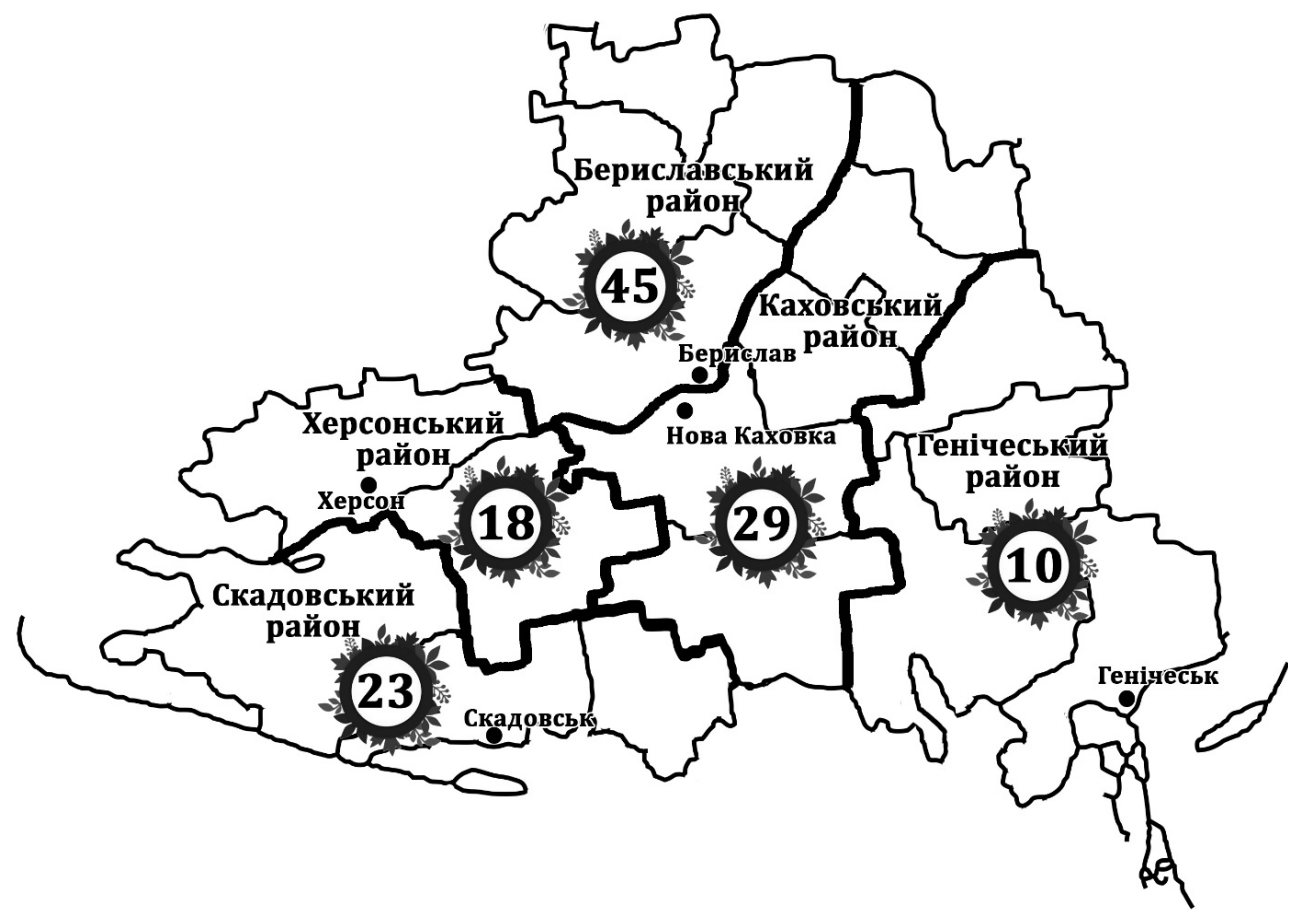

Рис. 1. Кількісний склад об'єктів Херсонщини по районах, які входять до перспективного плану під заповідання

Джерело: розроблено за даними [1; 4]

Херсонщина 3 липня 2020 р. має 5 районів, відповідно до чого був здійснений розподіл територій, які в перспективі поповнять природно-заповідний фонд регіону. 
3 рис. 1 видно, що Бериславский район має найбільшу кількість об’єктів, які підлягають під заповідання, а саме 45, найменший показник має Генічеський район, а саме 10 , інші три райони мають у кількісному складі середній показник територій під заповідання порівняно зі згаданими двома районами вище. Перелік планових об'єктів під заповідання становить 125 із загальною площею 161 264,8 га, що становить 5,67\% території області, тобто кількість об'єктів природно-заповідного фонду Херсонщини може збільшитися до 207 з площею 490 092,5 га, що дасть змогу збільшити частку заповідання регіону до 16,57\% та наблизитися до показника, який визначений загальнодержавною стратегією, а це 17,9\%.

До об'єктів, які сьогодні підлягають заповіданню в Херсонській області найближчим часом, віднесено такі [4]:

- регіональні ландшафтні парки: «Гаврилівський», «Гілея», «Долина курганів»;

- ландшафтні заказники загальнодержавного значення: «Арабатський степ», «Бобровий Кут», «Бургунська балка», «Василівська балка», «В’яземський», «Дончиха», «Забарине», «Західний Сиваш», «Короводинський», «Озеро Соколовське», «Острови Коянли», «Рогачик», «Старошведський», «Тягинська балка», «Узбережжя Чонгарської протоки», «Чорна Долина»;

- ботанічні заказники загальнодержавного значення: «Барнашівський під», «Зелений під», «Кардашинське болото», «Малий Чапельський під», «Пригірський», «Степовий під Гарбузи», «Шилова балка»;

- ландшафтні заказники місцевого значення;

- ботанічні заказники місцевого значення;

- гідрологічні заказники: «Бехтерські озера»;

- загальнозоологічні заказники: «Ягорлицький степ»;

- орнітологічні заказники: «Каланчацькі острови імені Т.Б. Ардамацької»;

- геологічні пам’ятки природи місцевого значення: «Відслонення відкладів міоцену біля села Львове»;

- ландшафтні пам’ятки природи місцевого значення: «Острівець»;

- комплексні пам’ятки природи місцевого значення: «Байди-Бомбандери»;

- ботанічні пам'ятки природи місцевого значення;

- кургани.

Перелік об'єктів під заповідання, що знаходяться в регіоні, $є$ широким, а також $є$ ті об'єкти, які вже перебувають на межі винищення, тому слід вжити низку заходів, які сформують належні умови для збереження первозданності місцевої флори та фауни. Для формування першочергових кроків щодо розширення ПЗФ слід визначитися 3 наявним переліком факторів, що стримує розширення ПЗФ Херсонської області, до яких перш за все можна віднести такі:

- антропогенний тиск;

- бюрократичний підхід до формування ПЗФ регіону;

- нецільове використання територій (вилучення земель під інші господарські потреби);

- розораність земель.

Бюрократичний підхід до формування ПЗФ регіону - це низка перепон, бар'єрів на етапах переведення територій під заповідання, що відбувається з боку як державних органів влади, так і місцевих. Під нецільовим використанням території регіону розуміється переведення заповідних територій під сільське господарство, а також сюди віднесені засмічення вод, лісів та урочищ, вирубка дерев, самовільне захоплення заповідних земель, браконьєрство. Ще одним чинником, який має свій вплив, $є$ розораність земель регіону. Сьогодні Херсонська область $є$ найбільш синантропізованою серед усіх областей Україні. Суттєвих змін зазнали степові ландшафти через свої чорноземи та легкість їх освоєння. Однак, незважаючи на це, Херсонщина повинна рухатися 
перспективним планом заповідання територій регіону та долати негативні фактори, 3 якими доводиться стикатися, щоби зберегти свою культурну, природну та рекреаційну спадщину.

Висновки. Планомірне здійснення систематичного заповідання територій Херсонщини сприятиме збереженню екосистеми в її первозданному вигляді. Отримання статусу охоронного об'єкта державного чи місцевого рівня гарантує цій території недоторканість та розвиток унікальних природних анклавів, а також стимулює розвиток рекреаційної діяльності. Також розширення переліку об'єктів природно-заповідного фонду Херсонської області та збереження наявних заповідних територій мають позитивний ефект щодо розвитку рекреаційної та оздоровчої діяльності, що дасть змогу здійснювати такі дії:

- оптимізувати рекреаційне використання територій та об'єктів ПЗФ, визначити допустимі рекреаційні навантаження на природні комплекси;

- сприяти розвитку спеціальних видів туризму, зокрема спостереження за тваринами, походи маршрутами історичних і літературних героїв;

- забезпечити реалізацію економічних проєктів установ ПЗФ у сфері рекреації та інших видів господарської діяльності в тих ії̈ формах, що не руйнують і не пошкоджують навколишнє природне середовище;

- сприяти залученню місцевого населення та громад до рекреаційної діяльності, зокрема до сільського та екотуризму.

Реалізація цих напрямів забезпечить створення сприятливих умов для відпочинку та оздоровлення населення в природних умовах, сталий розвиток громад та регіону, формування нових робочих місць.

\section{Список використаних джерел:}

1. Кирилов Ю.С., Присяжнюк П.В. Стан та соціально-економічне обгрунтування створення мережі заповідних територій Херсонської області. Держава та регіони. Серія: Економіка та підприємництво. 2020. № 2 (113). С. 197-201.

2. Кравченко О.В. Правовий режим природно-заповідного фонду України: історія формування, юридичні аспекти та закордонний досвід. Львів : Манускрипт, 2017. 92 с.

3. Мойсієнко I.I. Нові перспективні в туристичному відношенні об'єкти природно-заповідного фонду на Херсонщині. Розвиток екологічного туризму в краӥнах Чорноморського басейну: ресурси та інновачії : збірник тез доповідей. Херсон : ПП Вишемирський В.С., 2012. С. 51-53.

4. Мойсієнко I.I., Ходосовцев О.С., Пилипенко І.О., Бойко М.Ф., Мальчикова Д.С., Клименко В.М., Пономарьова А.А., Захарова М.Я., Дармостук В.В. Перспективні заповідні об'єкти Херсонської області. Херсон : Видавничий дім «Гельветика», 2020. 166 с. DOI: 10.32782/978966-992-049-2/1-166.

5. Природно-заповідний фонд України. URL: https://uk.wikipedia.org/wiki; pzf.menr.gov.ua (дата звернення: 01.12.2020).

6. Природно-заповідний фонд Херсонської області. URL: http://www.library; kherson.ua/ young/eco/9.htm (дата звернення: 01.12.2020).

7. Про природно-заповідний фонд України : Закон України від 16 червня 1992 р. № 2457XII / Верховна Рада України. URL: https://zakon.rada.gov.ua/laws/show/2456-12 (дата звернення: 01.12.2020).

\section{References:}

1. Kyrylov Yu.Ie., Prysiazhniuk P.V. (2020) Stan ta sotsialno-ekonomichne obgruntuvannia stvorennia merezhi zapovidnykh terytorii Khersonskoi oblasti [Status and socio-economic justification for the creation of a network of protected areas in the Kherson region]. Derzhava ta rehiony. Seriia: Ekonomika ta pidpryiemnytstvo, no. 2 (113), pp. 197-201.

2. Kravchenko O.V. (2017) Pravovyi rezhym pryrodno-zapovidnoho fondu Ukrainy: istoriia formuvannia, yurydychni aspekty ta zakordonnyi dosvid [Legal regime of the nature reserve fund of Ukraine: history of formation, legal aspects and foreign experience]. Lviv: Manuskrypt. (in Ukrainian) 
3. Moisiienko I.I. (2012) Novi perspektyvni $v$ turystychnomu vidnoshenni obiekty pryrodno-zapovidnoho fondu na Khersonshchyni. [New promising in terms of tourism objects of the nature reserve fund in the Kherson region]. Rozvytok ekolohichnoho turyzmu v krainakh Chornomorskoho baseinu: resursy ta innovatsii: zbirnyk tez dopovidei. Kherson: PP Vyshemyrskyi V.S., pp. 51-53.

4. Moysiyenko I.I., Khodosovtsev A.Ye., Pylypenko I.O., Boiko M.F., Malchykova D.S., Klymenko V.M., Ponomarova A.A., Darmostuk V.V., Zaharova M.Ya. (2020) Perspektyvni zapovidni obiekty Khersonskoi oblasti [Perspective nature protected objects of Kherson region]. Kherson: Helvetica. DOI: 10.32782/978-966-992-049-2/1-166.

5. Pryrodno-zapovidnyi fond Ukrainy [Nature Reserve Fund of Ukraine] Available at: https://uk.wikipedia.org/wiki; pzf.menr.gov.ua (accessed 01 December 2020).

6. Pryrodno-zapovidnyi fond Khersonskoi oblasti [Nature Reserve Fund of Kherson region]. Available at: http://www.library; kherson.ua/young/eco/9.htm (accessed 01 December 2020).

7. Pro pryrodno-zapovidnyi fond Ukrainy : Zakon Ukrainy vid 16.06 .92 r. № 2457-XII [On the Nature Reserve Fund of Ukraine: Law of Ukraine of June 16, 92 No. 2457-XII] / Verkhovna Rada Ukrainy. Available at: https://zakon.rada.gov.ua/laws/show/2456-12 (accessed 01 December 2020). 